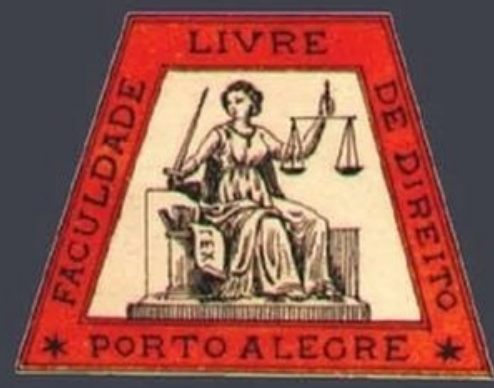

\title{
A retificação do registro civil de pessoas transgênero na América do Sul em perspectiva comparada
}

The rectification of transsexuals in civil registry in South America countries

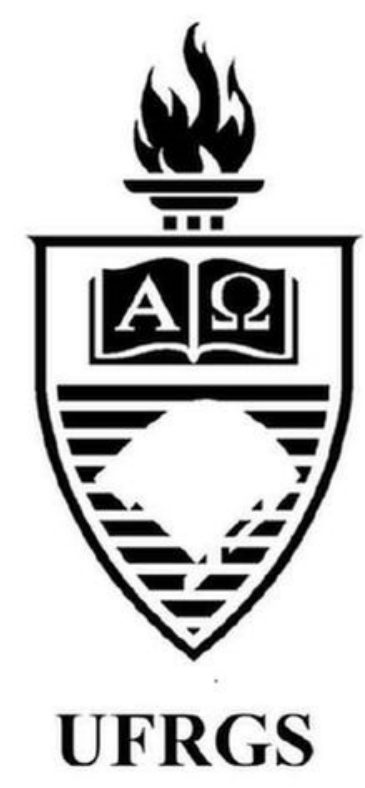

Maria Luiza Moura de Carvalho Universidade de São Paulo 


\section{A retificação do registro civil de pessoas transgênero na América do Sul em perspectiva comparada}

The rectification of transsexuals in civil registry in South America countries

Maria Luiza Moura de Carvalho*

\section{REFERÊNCIA}

CARVALHO, Maria Luiza Moura de. A retificação do registro civil de pessoas transgênero na América do Sul em perspectiva comparada. Revista da Faculdade de Direito da UFRGS, Porto Alegre, n. 39, vol. esp., p. 67-91, dez. 2018.

\section{RESUMO}

Este artigo apresenta uma análise comparativa entre a legislação dos dez países da América do Sul integrantes do sistema interamericano de direitos humanos no que concerne à demanda de pessoas transgênero por retificação da menção de sexo no registro civil, a partir de uma perspectiva despatologizante. Após uma perspectiva geral da situação nos países mencionados, passa-se a uma análise crítica específica sobre o estado atual da questão no Brasil, tanto no que concerne às diretrizes legais no âmbito da saúde quanto no que se refere às normas de direito registral, apresentando, por fim, o projeto de lei brasileiro relativo à identidade de gênero, inspirado na legislação argentina sobre a matéria.

\section{PALAVRAS-CHAVE}

Transexualidade. Direito Internacional dos Direitos Humanos. Direito comparado.

\section{ABSTRACT}

This paper sought to analyze comparatively the legislation of the ten south American countries that are part of the Inter-American Human Rights System, regarding the civil registry rectification of transsexuals from a nonpathologizing perspective. After a general overview of the situation in the mentioned countries, a specific critical analysis is carried out on the current state of the issue in Brazil, in terms of legal guidelines in health and civil registration, presenting, in the end, the Brazilian bill on gender identity, inspired by the Argentine legislation, is presented.

\section{KEYWORDS}

Transsexuality. International Human Rights. Comparative Law.

\section{SUMÁRIO}

Introdução. 1 A retificação registral de pessoas transgênero nos países da América do Sul em perspectiva comparada. 1.1 Paraguai. 1.2 Venezuela. 1.3 Bolívia. 1.4 Brasil. 1.5 Chile. 1.6 Peru. 1.7 Equador. 1.8 Uruguai. 1.9 Argentina. 1.10 Colômbia. 2 O caso brasileiro: estado da questão trans na Saúde e no Direito brasileiros. 2.1 As normativas sobre transexualidade no âmbito da Saúde. 2.2 A retificação de nome e da menção de sexo no registro civil de transgêneros. $2.3 \mathrm{O}$ projeto de lei de identidade de gênero brasileiro. Conclusão. Referências.

\footnotetext{
* Mestre e Bacharel em Direito pela Faculdade de Direito da Universidade de São Paulo. Doutoranda (2017-2020) pela Faculdade de Direito da Universidade de São Paulo e Faculdade de Direito da Universidade de Montréal.
} 


\section{INTRODUÇÃO}

O presente artigo busca apresentar uma análise comparativa entre as legislações de dez países latino-americanos no que se refere à demanda de pessoas transgênero por retificação de seu registro civil quanto à menção de sexo. Tal análise é fruto de parte da pesquisa de mestrado desenvolvida pela autora no âmbito do programa de pós-graduação em Direitos Humanos da Faculdade de Direito da Universidade de São Paulo, ${ }^{1}$ pesquisa que buscou desenvolver a temática do reconhecimento jurídico das demandas transidentitárias a partir da perspectiva e dos fundamentos teóricos da proteção internacional dos direitos humanos, ou seja, a partir de uma perspectiva de salvaguarda da dignidade humana dos indivíduos ainda que frente a padrões valorativos hegemônicos em determinadas épocas e locais.

É certo que se as ciências médicas, a teoria social tradicional e o senso comum em geral partem do pressuposto, "por um lado determinista e por outro construtivista” (ARÁN, 2006, p. 50), de que o sexo seria um dado natural, a-histórico, definido pela natureza e fundado no corpo orgânico, biológico e genético, enquanto o gênero seria adquirido por meio da cultura, sendo uma construção histórica e social (ARÁN, 2006), a perspectiva mais atual nas Ciências Sociais e adotada neste artigo, por outro lado, parte do pressuposto de que o sexo não é um simples fato ou uma condição estática da pessoa, mas antes "uma construção ideal forçosamente materializada através do tempo" (BUTLER, 1999, p.154).

\footnotetext{
${ }^{1}$ Dissertação pendente de publicação no Banco de Teses da Universidade de São Paulo até a data final de submissão deste artigo, 15 de maio de 2017.

2 Para uma análise da jurisprudência recente sobre retificação registral para transgêneros, vide artigo da autora publicado na Revista Áskesis, disponível em <http://www.revistaaskesis.ufscar.br/index.php/askesis/arti cle/view/178>, bem como a dissertação de mestrado de
}

Tal perspectiva encontra-se apoiada em evidências históricas que demonstram que a modernidade ocidental produziu um modelo de dois sexos como uma nova forma de interpretar a diferença sexual, na qual se estabeleceu uma distinção ontológica e horizontal entre o masculino e o feminino (LAQUEUR, 2001) por meio de um sistema epistemológico determinista no qual a ciência serve à cultura com o objetivo de fundar, na natureza dos corpos, a organização sexual culturalmente hierárquica da sociedade (ARÁN, 2006).

Assim, quase tudo que se queira dizer sobre o sexo já contém em si uma reinvindicação sobre o gênero, como se pode constatar nas decisões judiciais que condicionam a retificação registral à certificação médica de que o requerente sofre de uma patologia psíquica, ${ }^{2}$ em que a visão que prevalece é a de que as existências transgêneras, dada sua condição patológica, demandariam tutela tanto nos aspectos privados e subjetivos da experiência pessoal e íntima de gênero, quanto nos aspectos públicos da vida.

O gênero, entretanto, tampouco é uma simples construção social decorrente de uma matéria antes determinada - o sexo -, tal como concebido pelo construcionismo social, mas sim um efeito performático que adquire estabilidade em função da repetição e da reiteração das normas sociais (BUTLER, 1999), sem entretanto nunca se estabilizar definitivamente e de uma vez por todas, dado que os corpos não obedecem sempre nem por completo as normas pelas quais sua materialidade é fabricada (ARÁN, 2006).

A partir dessa perspectiva crítica sobre sexo e gênero, tem se consolidado nas Ciências Sociais

Luiza Ferreira Lima, intitulada "A verdade produzida nos autos: uma análise de decisões judiciais sobre retificação de registro civil de pessoas transexuais em tribunais brasileiros", defendida em 2015 pelo Programa de PósGraduação em Antropologia Social da Universidade de São Paulo, disponível $<$ http://www.teses.usp.br/teses/disponiveis/8/8134/tde22122015-094918/pt-br.php>; 
a perspectiva segundo a qual as experiências transidentitárias não teriam de médico "senão o fato contingente de serem repertoriada entre as síndromes psiquiátricas" (CASTEL, 2001, p. 90), muito embora a transexualidade permaneça como categoria nosológica nos dois principais compêndios médicos de referência, o Catálogo Internacional de Doenças e Problemas Relacionados à Saúde (OMS, 2008) e o Manual Diagnóstico Médico (APA, 2013).

A perspectiva despatologizante sobre o fenômeno transidentitário, portanto, segue a linha da observação de Canguilhem (2009), segundo a qual, em se tratando de seres vivos, a anormalidade nunca é patológica, mas, pelo contrário, o mais natural dos acontecimentos, sendo que uma eventual condição anômala somente torna-se enfermidade acaso produza efeitos limitadores para a vida das pessoas afetadas.

No caso das expressões de gênero contra majoritárias essa observação é especialmente pertinente, na medida em que não parece ser a condição biológica ou psicológica da pessoa o que lhe produz limitações, mas sim o meio social cisheteronormativo ${ }^{3}$ que, por impor restrições e dificuldades à vida íntima e pública das pessoas trans, é o que de fato se configuraria como agente patogênico da "disforia de gênero".

Entretanto, em sentido oposto à perspectiva despatologizante, a patologização das experiências trans continua operando com grande força. Isso se dá em parte na medida em que, sob a perspectiva tradicional, "o gênero só consegue sua inteligibilidade quando referido à diferença

\footnotetext{
3 O termo cis-heteronormatividade é utilizado nesse trabalho para se referir à continuidade pressuposta no meio social, bem como em suas instituições e normas legais, entre anatomia, sexo, gênero e desejo sexual a partir de uma compreensão heterossexual e cisgênera. $\mathrm{O}$ termo cisgênero, por sua vez, começou a ser utilizado há alguns anos nos meios não acadêmicos em contraposição à transgênero, ou seja, para se referir àquelas pessoas cuja expressão de gênero não romperia com as expectativas sociais para seu sexo (genitália). Embora o uso do termo para rotular pessoas
}

sexual e à complementaridade dos sexos" (BENTO; PELÚCIO, 2012, p. 572).

A consequência inevitável disso, então, é o surgimento dos transtornados de gênero, categoria nosológica que descreve, na perspectiva tradicional de gênero, todos aqueles que contrariam "a coerência essencial entre sexo biológico e gênero" (MURTA, 2007, p. 24), não se encaixando em nenhum dos modelos culturalmente hegemônicos de gênero ou identidade sexual. A partir disso atribui-se aos saberes médicos a decisão sobre a verdade dos corpos e mentes trans e ao poder judiciário a decisão, a partir dessas "verdades" estabelecidas, sobre aspectos fundamentais da vida em sociedade dessas pessoas, como sua identificação e qualificação civil.

Todas essas são evidências que parecem indicar que na análise das demandas trans os saberes médico e psi são tomados como únicos legitimados para dizer sobre a verdade dos corpos e mentes dessa parcela da população, acionando saberes que tomam a continuidade heteronormativa entre sexo e gênero como natural e sua descontinuidade como categoria diagnóstica, compreensão do fenômeno que inverte a relação entre causa e consequência, tratando a expressão de gênero como algo natural - e não social -, e as consequências vulnerabilizantes da não identificação aos padrões hegemônicos como sintomas de uma patologia localizada no indivíduo - e não como consequência da adesão conservadora por parte da sociedade, inclusive pelos operadores da Saúde e do Direito, a um rígido binarismo de gênero.

reais seja bastante controverso - como igualmente o é o termo transgênero -, entre outros motivos pois continua operando binaria e opositivamente e pressupõe que o ideal normativo de gênero seria reiterado indistintamente por todos aqueles que não se enquadram na categoria trans, entende-se que se trata de termo que mantem sua operacionalidade em alguns contextos, como quando utilizado para explicar justamente o funcionamento do modelo de pensamento cis-heteronormativo. 
De outra forma, se se partir do pressuposto de que há múltiplas possibilidades de experiências e práticas de gênero, então se teria mais facilidade em compreender que pessoas que demandam a retificação de seus registros para um gênero com o qual se identificam são pessoas totalmente capazes de dizer sobre aspectos personalíssimos de sua experiência subjetiva e identitária de gênero. A partir dessa compreensão e reconhecimento, não haveria justificativa para abordar suas demandas a partir do marco patologizante, o qual acaba por se configurar como vetor de patologização e estigma e, consequentemente, de limitação à autonomia e direitos às pessoas trans.

Cabe refletir portanto se compreender o sexo a partir de uma perspectiva essencialista - e, como consequência, o fenômeno transidentitário a partir da perspectiva patológica -, não seria um dos principais responsáveis pela persistência de padrões discriminatórios em relação às pessoas transgênero e obstáculo para a superação da transfobia institucionalizada no seio das instituições públicas e privadas.

Tais padrões, fundados em concepções expressas ou implicitamente essencialistas e biologizantes sobre a relação entre sexo e gênero, encontram-se em contradição com os documentos jurídicos internacionais sobre a matéria ${ }^{4}$ e com a bibliografia nacional e internacional especializada em gênero e identidade nas Ciências Sociais, que há pelo menos duas décadas passou a trabalhar com uma compreensão de gênero como aspecto da subjetividade humana desvinculado de qualquer determinismo biológico, o que indica

\footnotetext{
${ }^{4}$ Cujo exemplo principal são os Princípios de Yogyakarta sobre a aplicação da legislação internacional de direitos humanos em relação à orientação sexual e identidade de gênero, documento com caráter recomendatório elaborado a partir de um encontro realizado em novembro de 2006 na Universidade Gadjah Mada, na cidade indonesa de Yogyakarta, e que reuniu um grupo de 29 especialistas em Direitos Humanos e Direito Internacional de diversos países. Os Princípios foram lançados no Brasil, um dos países que o patrocinou, em agosto de 2007. A tradução
}

que abordar as demandas registrais trans para além de uma apreensão medicalisante do fenômeno transidentitário é não apenas uma necessidade ética do pesquisador e do operador do Direito, mas também uma exigência de atualização teórica em relação ao campo de estudo de gênero e sexualidades.

\section{A RETIFICAÇÃO REGISTRAL DE PESSOAS TRANSGÊNERO NOS PAÍSES DA AMÉRICA DO SUL EM PERSPECTIVA COMPARADA}

Por meio de uma análise comparativa entre as legislações aplicável às demandas transidentitárias de Argentina, Bolívia, Brasil, Chile, Colômbia, Equador, Paraguai, Peru, Uruguai e Venezuela, os dez países da América do Sul que integram também o Sistema Interamericano de Direitos Humanos da Organização dos Estados Americanos, buscou-se verificar a presença de pressupostos essencializantes/biologizantes implícitos quanto à relação entre os conceitos de sexo e gênero.

Mais especificamente, analisa-se se a patologização das identidades transgêneras figura ou não como requisito para o reconhecimento jurídico da demanda de indivíduos trans para a retificação registral e, em caso positivo, se exigese também procedimentos de redesignação sexual ${ }^{5}$ como requisito para o reconhecimento desse direito.

Resumidamente, temos o seguinte cenário: os dez países analisados podem ser subdivididos em quatro grupos a partir do critério quanto a

oficial em francês dos Princípios está disponível em $<$ http://www.yogyakartaprinciples.org/principles_fr.pdf $>$.

${ }^{5}$ Utiliza-se aqui o termo 'redesignação sexual' em lugar de 'cirurgia transgenitalizadora' sobretudo tendo em conta as diferenças entre o processo transexualizador de mulheres e homens transexuais, o qual no caso desses geralmente se restringe à administração de hormônios e a cirurgia de outros órgãos que não os propriamente genitais, como a retirada das mamas, útero e ovários, sendo portanto inexato falar-se em transgenitalização. 
condicionarem ou não o direito à retificação do nome e sexo no registro civil de transexuais à realização de procedimentos médicos de redesignação sexual e/ou à patologização das identidades de gênero trans.

O primeiro destes grupos é composto por Paraguai e Venezuela, países que patologizam as experiências trans e não permitem a retificação registral em nenhuma hipótese. O segundo grupo é comporto por Bolívia, Brasil, Chile e Peru, países que patologizam as experiências trans, mas excepcionalmente permitem a retificação registral, condicionando-a, porém, à redesignação sexual completa, em regra.

No terceiro grupo encontra-se apenas o Uruguai, em que há lei de identidade de gênero permitindo a retificação registral independentemente da redesignação sexual completa, mas ainda assim o fenômeno trans segue sendo compreendido a partir da perspectiva patologizante. O quarto grupo é formado por Colômbia, Equador e Argentina, países que não patologizam as experiências transidentitárias nem condicionam a retificação registral à redesignação sexual.

Vejamos em resumo a situação em cada um dos países em relação à existência de normativa específica contra discriminação de gênero e quanto à retificação registral de pessoas trans.

\subsection{Paraguai}

No Paraguai, em termos de legislação contra discriminação, embora o art. 46 da Constituição Paraguaia reconheça a igualdade entre todas as pessoas e expressamente não admita discriminação (PARAGUAI, 1992) ${ }^{6}$, ainda não há regulamentação específica nesse sentido, sendo que o projeto de lei ${ }^{7}$ que pretende regulamentar o artigo mencionado, embora apresentado em 2007, ainda não foi votado. Portanto, não há nenhum dispositivo legal em nível nacional que promova a proteção contra a discriminação fundada especificamente em identidade de gênero.

Tampouco há qualquer norma assegurando o direito à retificação registral de pessoas trans, sendo que até mesmo a cirurgia de redesignação sexual não é regulamentada, sendo que o art. 112 do Código Penal paraguaio considera que comete lesão corporal grave aquele que intencional ou conscientemente provoque em outro, por conta da lesão, redução considerável e por longo período do uso de seu corpo ou sentidos (PARAGUAI, 1997).

\subsection{Venezuela}

$\mathrm{Na}$ Venezuela, em termos de lei contra discriminação, embora quando da adoção da nova Constituição venezuelana (VENEZUELA, 1999) tenham sido propostos artigos específicos vedando expressamente a discriminação, estes ficaram de fora do texto final por conta da firme oposição de setores da Igreja Católica. ${ }^{8}$ Não há qualquer legislação específica sobre identidade de gênero ou retificação registral para pessoas trans e o art. 417 do Código Penal venezuelano considera lesão corporal $\mathrm{o}$ ato que cause inabilitação permanente de algum sentido ou órgão (VENEZUELA, 2000).

\subsection{Bolívia}

\footnotetext{
${ }^{7}$ Disponível em: <http://www.unfpa.org.py/nodiscriminacion/anteproyecto_ e_Ley_contra_Toda_Forma_de_Discriminacion.pdf $>$ 8 Vide informações disponíveis em https://en.wikipedia.org/wiki/LGBT_rights_in_Venezuela
} 
Na Bolívia há norma constitucional e legal vedando a discriminação baseada em orientação sexual e identidade de gênero, a exemplo do inciso II do art. 14 da Constituição da Bolívia (BOLÍVIA, 2009) ${ }^{9}$ e do art. 281, sexto, do Código Penal, acrescentado pela Lei contra o racismo e toda forma de discriminação, de 2010, passando assim a criminalizar discriminações baseadas na orientação e identidade de gênero (BOLÍVIA, 1972)..$^{10}$

O país, entretanto, não possui legislação nacional específica sobre identidade de gênero ou retificação registral para pessoas trans, o que deve ser requerido judicialmente, tal como no Brasil. Quanto à cirurgia de redesignação sexual, é permitida e inclusive um dos requisitos para pleitear judicialmente a retificação de nome e sexo nos registros.

\subsection{Brasil}

No Brasil, embora a Constituição de 1988 proíba genericamente qualquer forma de discriminação (BRASIL, 1988), não há qualquer referência específica à discriminação motivada por identidade de gênero, tampouco legislação específica sobre identidade de gênero ou retificação registral para pessoas trans, o que deve ser requerido judicialmente.

\footnotetext{
${ }^{9}$ In verrbis: "El Estado prohíbe y sanciona toda forma de discriminación fundada en razón de sexo, color, edad, orientación sexual, identidad de género, origen, cultura, nacionalidad, ciudadanía, idioma, credo religioso, ideología, filiación política o filosófica, estado civil, condición económica o social, tipo de ocupación, grado de instrucción, discapacidad, embarazo, u otras que tengan por objetivo o resultado anular o menoscabar el reconocimiento, goce o ejercicio, en condiciones de igualdad, de los derechos de toda persona" (BOLÍVIA, 2009).

${ }^{10}$ In verbis: "Artículo 281 Sexies.- (DISCRIMINACIÓN). I. La persona que arbitrariamente e ilegalmente obstruya, restrinja, menoscabe, impida o anule el ejercicio de los derechos individuales y colectivos, por motivos de sexo, edad, género, orientación sexual e identidad de género, identidad cultural, filiación familiar, nacionalidad, ciudadanía, idioma, credo religioso, ideología, opinión política o filosófica, estado civil, condición económica o social, enfermedad, tipo de ocupación, grado de instrucción,
}

\subsection{Chile}

No Chile, embora exista proteção legal em nível nacional contra a discriminação fundada em orientação sexual (CHILE, 2012), o texto da Lei $n^{\circ} 20.609 / 2012$, estabelecendo medidas contra a discriminação, não inclui expressamente a discriminação fundada na identidade de gênero. Quanto à cirurgia de redesignação sexual, é permitida e obrigatória para conseguir a retificação de nome e sexo no registro civil, que deve ser requerida judicialmente.

Embora o país não possua legislação específica sobre identidade de gênero ou retificação registral para pessoas trans, há projeto de lei específico, de $\mathrm{n}^{\circ}$ 8924-07 (CHILE, 2013) apresentado ao Senado em sete de maio de $2013^{11}$ e ainda em análise nessa Casa.

Tal qual o projeto brasileiro, o projeto chileno tem clara inspiração na lei de identidade de gênero Argentina e prevê a possibilidade de mudança de nome e retificação da anotação de sexo no registro civil independentemente da realização de cirurgia de transgenitalização ou qualquer outra intervenção cirúrgica, hormonal ou de qualquer índole.

Tampouco se exige prova ou diagnóstico de disforia de gênero, bastando que se ateste que o

capacidades diferentes o discapacidad física, intelectual o sensorial, estado de embarazo, procedencia regional, apariencia física y vestimenta, será sancionado con pena privativa de libertad de uno (1) a cinco (5) años. II. La sanción será agravada en un tercio el mínimo y en una mitad el máximo cuando: a) El hecho sea cometido por una servidora o servidor público o autoridad pública. b) El hecho sea cometido por un particular en la prestación de un servicio público. c) El hecho sea cometido con violencia. (Incorporado por el Artículo 23 de la Ley No 045 de 08 de octubre de 2010, Contra el Racismo y toda forma de Discriminación y ordenado por el parágrafo II del Artículo Único del Decreto Supremo No 0667 de 08 de Octubre de 2010)".

11 Projeto de Lei n. 8.924-07. Link para acompanhamento da proposição: <https://www.camara.cl/pley/pley_detalle.aspx?prmID=93 31\&prmBL=8924-07>. 
demandante é conhecido em suas relações sociais por uma identidade de gênero que não coincide com o sexo que consta em seu registro. Diferentemente do projeto de lei brasileiro (2013a), da lei equatoriana (2015), colombiana (2015), argentina (2012) e uruguaia (2009), o PL chileno (2013) propõe que o procedimento para a retificação se dê no âmbito judicial, e não no meramente administrativo.

\subsection{Peru}

O Peru não possui legislação específica contra discriminação fundada em identidade de gênero e tampouco sobre retificação registral para pessoas trans, devendo a retificação do registro civil no caso de transexuais operados ser requerida judicialmente. Por conta disso, em 2012 foi apresentado o projeto de lei específico sobre o tema (PERU, 2012), ${ }^{12}$ ainda não votado, no sentido de permitir a retificação do nome de pessoas transexuais maiores de 18 anos por meio de simples procedimento administrativo sem exigência de cirurgia de redesignação sexual, esterilização, terapia hormonal ou atestado psicológico como requisito.

\subsection{Equador}

No Equador existe proteção constitucional expressa contra a discriminação fundada em

\footnotetext{
12 Texto do projeto disponível em $<$ https://pt.scribd.com/document/333423946/PL-deIdentidad-de-Genero-pdf\#from_embed $>$.

${ }^{13}$ In verbis: "Todas las personas son iguales y gozaran de los mismos derechos, deberes y oportunidades. Nadie podrá ser discriminado por razones de etnia, lugar de nacimiento, edad, sexo, identidad de género, identidad cultural, estado civil, idioma, religión, ideología, filiación política, pasado judicial, condición socio-económica, condición migratoria, orientación sexual, estado de salud, portar VIH, discapacidad, diferencia física; ni por cualquier otra distinción, personal o colectiva, temporal o permanente, que tenga por objeto o resultado menoscabar o anular el reconocimiento, goce o ejercicio de los derechos. La ley sancionará toda forma de discriminación. El Estado adoptará medidas de acción afirmativa que promuevan la
}

orientação sexual e identidade de gênero, nos termos do art. 11, inciso segundo, do texto constitucional (EQUADOR, 2008). ${ }^{13}$

Além disso, o país recentemente aprovou lei que assegura o direito à mudança voluntária de nome e sexo por parte de qualquer pessoa maior de 18 anos, uma única vez (EQUADOR, 2015), ${ }^{14}$ ficando assim garantido o direito à retificação registral de pessoas trans por meio de simples procedimento administrativo, independentemente de qualquer requisito médico ou judicial, bastando a auto identificação de gênero, se aproximando assim da sistemática existente na Argentina e Colômbia.

\subsection{Uruguai}

O Uruguai aprovou, em 2004, lei específica contra discriminação (URUGUAI, 2004), 15 contemplando expressamente aquelas fundadas na orientação sexual e na identidade de gênero. Além disso, o país foi o primeiro entre os da América do Sul a aprovar lei de identidade de gênero, regulando a retificação registral das pessoas trans, em 12 de outubro de 2009 (URUGUAI, 2009). ${ }^{16}$ Como consta de seu título, a lei visa assegurar o "direito à identidade de gênero e à mudança do nome e do sexo nos documentos de identificação (URUGUAI, 2009,

igualdad real en favor de los titulares de derechos que se encuentren en situación de desigualdad" (EQUADOR, 2008).

${ }^{14}$ Ley Orgánica de Gestión de la Identidad y Datos Civiles, aprovada em 10 de dezembro de 2015, vide notícia oficial disponível

<http://www.asambleanacional.gob.ec/es/noticia/40698asamblea-aprobo-ley-de-gestion-de-identidad-se-crea>

${ }^{15}$ Lei $\mathrm{n}^{\mathrm{o}} 17.817$, disponível em <http://www0.parlamento.gub.uy/leyes/AccesoTextoLey.a sp?Ley $=17817 \&$ Anchor $=>$.

16 Lei $\mathrm{n}^{\mathrm{o}}$ 18.620, disponível em $<$ https://legislativo.parlamento.gub.uy/temporales/leytemp 1965664.htm>. 
p. 1, em tradução livre ${ }^{17}$ ).

$\mathrm{O}$ artigo primeiro da lei afirma que "toda pessoa tem direito ao livre desenvolvimento de sua personalidade conforme sua própria identidade de gênero, independentemente de qual seja seu sexo biológico, genético, anatômico, morfológico, hormonal, de assignação ou outro" (URUGUAI, 2009, p. 1, em tradução livre ${ }^{18}$ ). Dispõe, ademais, que o direito à identidade de gênero inclui o direito "de ser identificado de forma que se reconheça plenamente a identidade de gênero pessoal e a consonância entre essa identidade e o nome e sexo assignados [em todos] os documentos identificatórios da pessoa [...]" (URUGUAI, 2009, p. 1, em tradução livre ${ }^{19}$ ).

$\mathrm{O}$ artigo segundo, por sua vez, tratando da legitimação para demandar o direito previsto na Lei, afirma que "toda pessoa poderá solicitar a adequação do registro de seu nome, sexo ou ambos quando os mesmos não coincidam com sua identidade de gênero" (URUGUAI, 2009, p. 1, em tradução livre ${ }^{20}$ ).

$\mathrm{O}$ artigo terceiro, tratando dos requisitos para tal demanda, dispõe que o direito previsto na Lei será acordado ao demandante desde que ele afirme que o nome, sexo, ou ambos, que constam em seu registro de nascimento, estão em discordância com sua identidade de gênero (URUGUAI, 2009). Além disso, exige-se a

\footnotetext{
17 No original, "Derecho a la identidad de género y al cambio de nombre y sexo en documentos identificatorios" (URUGUAI, 2009, p. 1).

18 No original: "Toda persona tiene derecho al libre desarrollo de su personalidad conforme a su propia identidad de género, con independencia de cuál sea su sexo biológico, genético, anatómico, morfológico, hormonal, de asignación u outro" (URUGUAI, 2009, p. 1).

${ }^{19}$ No original: "[..] identificado de forma que se reconozca plenamente la identidad de género propia y la consonancia entre esta identidad y el nombre y sexo señalado en los documentos identificatorios de la persona [...]" (URUGUAI, 2009, p. 1).

${ }^{20}$ No original: "Toda persona podrá solicitar la adecuación de la mención registral de su nombre, sexo, o ambos, cuando los mismos no coincidan con su identidad de género" (URUGUAI, 2009, p. 1).
}

"estabilidade e persistência de tal dissonância durante ao menos dois anos" (URUGUAI, 2009, p. 1, em tradução livre ${ }^{21}$ ), cuja prova é feita, nos termos do artigo quarto, através de um "informe técnico de equipe multidisciplinar e especializada em identidade de gênero e diversidade" (URUGUAI, 2009, p. 1, em tradução livre ${ }^{22}$ ). Para tanto se leva em conta, segundo a lei, especialmente o "testemunho das pessoas que conhecem a modo de vida cotidiano do demandante bem como dos profissionais que o tenham atendido" (URUGUAI, 2009, p. 1, em tradução livre ${ }^{23}$ ).

$\mathrm{O}$ artigo terceiro ainda dispõe expressamente que "em nenhum caso será exigida a cirurgia de redesignação sexual para a concessão da adequação registral prevista na lei" (URUGUAI, 2009, p. 1, em tradução livre ${ }^{24}$ ), seja ela a de nome ou de sexo. Ressalva a lei, entretanto, que caso a pessoa já tenha se submetido ao procedimento de redesignação sexual, não lhe será exigida a prova de estabilidade e persistência da dissonância por dois anos, que nos demais casos é exigida, conforme visto acima (URUGUAI, 2009).

Quanto ao procedimento e competência, dispõe o artigo quarto que será de iniciativa pessoal do demandante e tramitará perante os juizados de família, não podendo ser requerida

21 No original: "La estabilidad y persistencia de esta disonancia durante al menos dos años [...]" (URUGUAI, 2009, p. 1).

${ }^{22}$ No original: "La presentación de la demanda deberá estar acompañada de un informe técnico del equipo multidisciplinario y especializado en identidad de género y diversidad" (URUGUAI, 2009, p. 1).

${ }^{23}$ No original: “[...] se tendrá especialmente en cuenta el testimonio de las personas que conocen la forma de vida cotidiana del solicitante y la de los profesionales que lo han atendido desde el punto de vista social, mental y físico" (URUGUAI, 2009, p. 1).

24 No original: "En ningún caso se exigirá cirugía de reasignación sexual para la concesión de la adecuación registral de la mención del nombre o del sexo que fuere disonante de la identidad de género de la persona a que se hace referencia en dicho documento" (URUGUAI, 2009, p. 1). 
nova adequação registral antes de passados cinco anos, a partir de quando passa a ser possível nova alteração, mas apenas para o nome e sexo "originais" (URUGUAI, 2009). Por fim, a lei dispõe expressamente que a mudança registral não modifica o regime matrimonial e permite à pessoa exercer todos os direitos inerentes à sua nova condição (URUGUAI, 2009).

\subsection{Argentina}

$\mathrm{Na}$ Argentina, embora em alguns estados existam leis contra a discriminação fundada em orientação sexual e identidade de gênero, ainda está pendente lei federal nesse sentido. Por outro lado foi aprovada em 8 de maio de 2012 a Lei de Identidade de Gênero argentina (ARGENTINA, 2012), ${ }^{25}$ de $n^{\circ} 26.743$, a segunda do gênero entre os países da América do Sul, seguida da lei uruguaia, em relação a qual apresenta importantes avanços e serviu de inspiração para os projeto de lei de identidade de gênero brasileiro e chileno, ambos de 2013.

O texto da lei argentina é composto de quinze artigos, os quais abordam a definição do direito tutelado, a forma como se dará seu exercício, os requisitos exigidos, a sua aplicação a pessoas menores de idade, bem como os trâmites legais, os efeitos, os limites, a aplicação e outros aspectos da lei.

$\mathrm{O}$ artigo primeiro inicia reconhecendo a todas as pessoas o direito à identidade de gênero, ao livre desenvolvimento pessoal de acordo com sua identidade de gênero, bem como a ser tratada de acordo com essa auto identificação de gênero, em especial o direito a ser assim identificada nos documentos de identidade, sobretudo em relação ao nome, sexo e foto que neles constem

\footnotetext{
25 Lei $\mathrm{n}^{\mathrm{o}} 26.743, \quad$ disponível em <http://www.tgeu.org/sites/default/files/ley_26743.pdf>

${ }^{26}$ No original: "[...] la vivencia interna e individual del género tal como cada persona la siente, la cual puede corresponder o no con el sexo asignado al momento del nacimiento [...]" (ARGENTINA, 2012, p. 1).
}

(ARGENTINA, 2012).

$\mathrm{O}$ artigo segundo dispõe que se entende por identidade de gênero a "vivência interna e individual do gênero tal como cada pessoa o sente e que esta pode ou não corresponder com o sexo assignado no nascimento" (ARGENTINA, 2012, p. 1, em tradução livre $\left.{ }^{26}\right)$.

Os dois artigos seguintes $\left(3^{\circ}\right.$ e $\left.4^{\circ}\right)$ dispõem que "qualquer pessoa poderá solicitar a retificação registral do nome e sexo quando estes não coincidam com sua identidade de gênero autopercebida" (ARGENTINA, 2012, p. 1, em tradução livre ${ }^{27}$ ), desde que tenha mais de dezoito anos. Para tanto, basta que o interessado apresente uma solicitação ao registro civil requerendo a retificação dos documentos, fundamentando a demanda com a afirmação de que se encontra amparado pela lei de identidade de gênero, não se exigindo, em nenhum caso, intervenção cirúrgica de redesignação sexual total ou parcial, tampouco a submissão a terapias hormonais ou qualquer tratamento ou aconselhamento psicológico ou psiquiátrico (ARGENTINA, 2012).

Quanto às crianças e jovens menores de dezoito anos de idade, diz o artigo quinto que a requisição deve ser feita por meio de seus representantes legais com expresso consentimento do menor interessado e sempre com a assistência de um advogado que represente os interesses deste, tudo levando em conta os princípios da capacidade progressiva, do melhor interesse e da proteção integral dos direitos das crianças e adolescentes (ARGENTINA, 2012).

Em relação ao trâmite, dispõe o artigo sexto que:

[...] verificado os requisitos estabelecidos nos artigos $4^{\circ}$ e $5^{\circ}$ o funcionário deve desde logo, sem necessidade de qualquer processo judicial ou

\footnotetext{
${ }^{27}$ No original: “Toda persona podrá solicitar la rectificación registral del sexo, y el cambio de nombre de pila e imagen, cuando no coincidan con su identidad de género autopercibida" (ARGENTINA, 2012, p. 1).
} 
administrativo, notificar oficialmente a retificação do sexo e a mudança de nome para o cartório de registro civil da jurisdição onde se encontra registrada a certidão de nascimento para que este proceda à emissão de uma nova certidão a partir das retificações requeridas (ARGENTINA, 2012, p. 1, em tradução livre ${ }^{28}$ ).

O artigo sexto também estabelece ser proibida "qualquer referência a tais retificações tanto na nova certidão de nascimento quanto na nova carteira de identidade emitidas" (ARGENTINA, 2012, p. 1, em tradução livre ${ }^{29}$ ). Além disso, dispõe que "os procedimentos para tais retificações no registro são gratuitos, pessoais e independem da intermediação de advogados ou terceiros" (ARGENTINA, 2012, p. 1, em tradução livre ${ }^{30}$ ).

Quanto aos efeitos da retificação, dispõe o artigo sétimo que os mesmos serão oponíveis a terceiros a partir da modificação no registro, e que a retificação não altera a titularidade de direitos e obrigações legais aplicáveis à pessoa, nem mesmo os decorrentes do direito de família, que permanecerão imutáveis, incluindo os relativos à adoção (ARGENTINA, 2012).

Quanto à possibilidade de uma nova retificação registral com fundamento nos direitos protegidos pela lei de identidade de gênero, o artigo oitavo é expresso no sentido de que só é possível mediante autorização judicial. Quanto à confidencialidade da retificação, dispõe o artigo nono que só terão acesso à certidão de nascimento original aqueles que detenham ordem judicial

\footnotetext{
${ }^{28}$ No original: "Cumplidos los requisitos establecidos en los artículos $4^{\circ}$ y $5^{\circ}$, el/la oficial público procederá, sin necesidad de ningún trámite judicial o administrativo, a notificar de oficio la rectificación de sexo y cambio de nombre de pila al Registro Civil de la jurisdicción donde fue asentada el acta de nacimiento para que proceda a emitir una nueva partida de nacimiento ajustándola a dichos câmbios [...]" (ARGENTINA, 2012, p. 1).

${ }^{29}$ No original: "[...] cualquier referencia a la presente ley en la partida de nacimiento rectificada y en el documento nacional de identidad expedido en virtud de la misma" (ARGENTINA, 2012, p. 1).

${ }^{30}$ No original: "Los trámites para la rectificación registral previstos en la presente ley son gratuitos, personales y no
}

fundamentada ou autorização do próprio titular das informações (ARGENTINA, 2012).

Os artigos seguintes seguem tratando sobre o direito à dignidade e ao livre desenvolvimento da personalidade, dispondo que a lei assegura igualmente o direito à saúde em perspectiva integral, incluindo-se o acesso, sem necessidade de autorização judicial ou administrativa, a todos os meios para adequar o corpo à identidade de gênero auto percebida pela pessoa (ARGENTINA, 2012).

A lei inclui entre esses meios o acesso tanto aos procedimentos cirúrgicos de redesignação sexual quanto aos tratamentos hormonais, bastando para tanto apenas o consentimento livre e esclarecido do interessado e cabendo aos gestores do sistema público de saúde garantir os direitos que a lei reconhece (ARGENTINA, 2012). Por fim, a lei se encerra dispondo que

[...] todas as normas, regulamentos e procedimentos devem respeitar o direito humano à identidade de gênero das pessoas, [não podendo] limitar, restringir, excluir ou suprimir o exercício do direito à identidade de gênero, devendo-se sempre serem interpretadas e aplicadas no sentido de garantir o acesso a tal direito (ARGENTINA, 2012, p. 1, em tradução livre ${ }^{31}$ ).

\subsection{Colômbia}

Na Colômbia foi aprovada em 2011 lei antidiscriminatória $^{32}$ que, embora faça referência à orientação sexual, nada diz quanto à identidade

será necesaria la intermediación de ningún gestor o abogado" (ARGENTINA, 2012, p. 1).

$31 \mathrm{~N}$ original: "Toda norma, reglamentación $\mathrm{O}$ procedimiento deberá respetar el derecho humano a la identidad de género de las personas. Ninguna norma, reglamentación o procedimiento podrá limitar, restringir, excluir o suprimir el ejercicio del derecho a la identidad de género de las personas, debiendo interpretarse y aplicarse las normas siempre a favor del acceso al mismo" (ARGENTINA, 2012, p. 1).

32 Lei $\mathrm{n}^{\circ}$ 1.482, disponível em: <http://wsp.presidencia.gov.co/Normativa/Leyes/Documen ts/ley148230112011.pdf>. 
de gênero (COLÔMBIA, 2011). Em 2015, por sua vez, foi expedido o Decreto Executivo $\mathrm{n}^{\circ} 1227,{ }^{33}$ passando a garantir o direito à retificação de sexo e gênero no registro civil de transexuais independentemente de cirurgia de redesignação sexual, diagnóstico médico ou requisição judicial, bastando que o interessado firme autodeclaração por escritura pública lavrada em cartório de registros públicos referindo-se à construção sociocultural de sua identidade de gênero, não se exigindo nenhuma prova ou documentação a esse respeito (COLÔMBIA, 2015a). ${ }^{34}$

Tal decreto vem no sentido de adequar-se à sentença vinculante prolatada em 2015 pela Corte Constitucional da Colômbia (COLÔMBIA, 2015b), ${ }^{35}$ já que até então o procedimento para retificação, embora de natureza não contenciosa, era judicial e exigia-se a cirurgia de redesignação

\footnotetext{
${ }^{33}$ Decreto Executivo n. 1227, de 5 de junho 2015, disponível

de

em
}

$<$ https://www.minjusticia.gov.co/Portals/0/Ministerio/decr eto\%20unico/\%23\%20decretos/1.\%20DECRETO\%20201 5-1227\%20sexo\%20c\%C3\%A9dula.pdf $>$.

34 Vide informação constante na página eletrônica http://www.elespectador.com/entrevista-de-

ceciliaorozco/cambio-de-genero-cedula-sera-agil-y-

simple-minjusticia-articulo-564988, último acesso em 11 de maio de 2017.

${ }^{35}$ Dada sua importância e similitude com o estado da questão no Brasil, onde se tem observado uma tendência jurisprudencial pela flexibilização dos requisitos para a retificação registral de pessoas trans, traz-se à colação trechos selecionados dessa decisão que constam dos "considerandos" do citado Decreto: "Así las cosas, aunque de manera coloquial suele afirmarse que las personas transgénero experimentan un 'cambio de sexo', lo que ocurre en estos casos es que existe una discrepancia entre la hetero asignación efectuada al momento del nacimiento y consignada en el registro, y la auto definición identitaria que lleva a cabo el sujeto. En ese orden de ideas, de la misma forma en que la intervención quirúrgica se realiza para ajustar las características corporales de una persona a la identidad sexual asumida por esta no es propiamente una operación de "cambio de sexo", sino de "reafirmación sexual quirúrgica", la modificación de los datos del registro civil de las personas transgénero no responde a un cambio respecto de una realidad precedente, sino a la corrección de un error derivado de la falta de correspondencia entre el sexo asignado por terceros al momento de nacer y la adscripción identitaria que lleva a cabo el propio individuo, siendo esta última la que resulta relevante para efectos de la sexual como requisito indispensável.

\section{O CASO BRASILEIRO: ESTADO DA QUESTÃO TRANS NA SAÚDE E NO DIREITO BRASILEIROS}

\author{
Como visto, o Brasil não possui legislação
}

específica sobre identidade de gênero ou retificação registral para pessoas trans, o que deve ser requerido judicialmente. $\mathrm{O}$ deferimento de tais demandas quase sempre está condicionado, em primeiro lugar, à comprovação, por laudo médico, da chamada "condição transexual". Além disso, geralmente também condiciona-se a mudança da menção de sexo no registro civil à realização de cirurgias de redesignação sexual (VILARDO, 2014, p. 166), muito embora este último requisito venha sendo cada vez mais flexibilizado pelos tribunais estaduais. ${ }^{36}$

determinación de este elemento del estado civil.[...] En definitiva, la exigencia impuesta a las personas transgénero de acudir a la vía judicial para lograr la corrección del sexo inscrito en el registro civil, supone la afectación de múltiples derechos fundamentales a los que antes se hizo alusión y representa un trato desigual respecto del que se dispensa a las personas cisgénero. [...] La corrección por vía notarial reduce los obstáculos y exclusiones que padecen las personas transgénero en razón de los mayores costos y tiempos de espera que supone el recurso a un proceso judicial, y que en sus particulares condiciones de marginación y exclusión se convierten en una carga especialmente dura de afrontar; asimismo, elimina la diferencia de trato que se establece entre personas cisgénero y transgénero, permitiendo a estas últimas hacer uso del procedimiento de corrección del sexo en el registro que hoy se admite para las primeras y contribuye a eliminar la tendencia hacia la patologización de la identidad de género. Se trata, por tanto, de un medio menos lesivo en términos de afectación a derechos fundamentales. [...] Asimismo, la corrección a través de escritura pública permite lograr con el mismo grado de idoneidad las finalidades que se pretenden asegurar a través del procedimiento de jurisdicción voluntaria" (COLÔMBIA, 2015b, p. 1).

${ }^{36} \mathrm{O}$ Superior Tribunal de Justiça inclusive se manifestou recentemente, embora sem caráter vinculante, pela inexigibilidade da transgenitalização para a retificação da menção de sexo no registro civil de uma mulher transexual. Tal decisão foi prolatada pela quarta turma do Superior Tribunal de Justiça em 9 de maio de 2017, nos autos do Recurso Especial n. 1.626.739/RS. Segundo o ministro Luís Felipe Salomão, "Independentemente da realidade biológica, o registro civil deve retratar a identidade de 
A possibilidade de retificação registral de nome e sexo no registro civil de transgêneros independentemente de cirurgia de transgenitalização é também objeto da Ação Direta de Inconstitucionalidade $\mathrm{n}^{\circ} 4275^{37}$, proposta em 21 de julho de 2009 e ainda não julgada, de autoria da então procuradora-geral da República em exercício, Dra. Deborah Duprat.

Além disso, em vinte de fevereiro de 2013 os deputados federais Jean Wyllys (PSOL/RJ) e Érika Kokay (PT/DF) apresentaram à Câmara dos Deputados Federais o Projeto de Lei $n^{\circ}$ 5.002, denominado "Projeto de Lei sobre Identidade de Gênero - Lei João W. Nery" ${ }^{38}$, que tem clara inspiração na lei de identidade de gênero Argentina $^{39}$ e é abordado no item 2.3

\subsection{As normativas sobre transexualidade no âmbito da Saúde}

Embora desde meados da década de 1950 a cirurgia de transgenitalização seja considerada uma terapia para adequação genital ao "sexo psíquico" da pessoa transexual, tal intervenção manteve-se tipificada como crime de lesão corporal no Brasil até a publicação da Resolução $\mathrm{n}^{\circ} 1.482$ do Conselho Federal de Medicina (CFM), em 1997 (BRASIL, 1997). Segundo Arán et al. (2009, p. 1144):

[...] a legalização da cirurgia de transgenitalização e de procedimentos afins foi um processo longo e cercado de diversas discussões que tiveram início em 1979, quando o CFM foi consultado pela primeira vez sobre a inclusão de próteses mamárias em pacientes do sexo masculino.

Com a Resolução nº 1.482/97, do CFM,

gênero psicossocial da pessoa transexual, de quem não se pode exigir a cirurgia de transgenitalização para o gozo de um direito."

37 Petição inicial disponível em: <http://www.stf.jus.br/portal/geral/verPdfPaginado.asp?id $=400211 \&$ tipo $=$ TP\&descricao $=$ ADI\%2F4275 $>$.

38 Link para acompanhamento da proposição: http://www.camara.gov.br/proposicoesWeb/fichadetramita cao idProposicao $=565315$. ficaram autorizadas, em caráter experimental, as cirurgias do tipo neocolpovulvoplastia ${ }^{40}$, neofaloplastia ${ }^{41}$ e outros procedimentos de intervenção nas gônadas e caracteres sexuais secundários para $\mathrm{o}$ tratamento do "transexualismo" (TEIXEIRA, 2013), termos até então usado para se referir à vivência transidentitária. A partir dela:

[...] a intervenção cirúrgica passou a ser legítima no Brasil, desde que o paciente [apresentasse] os critérios necessários para a realização da mesma e o tratamento [seguisse] um programa rígido, que [incluía] a avaliação de equipe multidisciplinar e acompanhamento psiquiátrico por no mínimo dois anos, para a confirmação do diagnóstico de transexualismo (ARÁN; MURTA; LIONÇO, 2009, p. 1142).

Segundo Freire (2014), "a mudança de estatuto da cirurgia de transgenitalização, que deix[ou] de ser uma mutilação e pass[ou] a ser considerada terapêutica, [foi] acompanhada pela modificação da moralidade que cerca a transexualidade" (FREIRE, 2014, p. 23), que teria deixado de ser vista como "desvio moral" para ser considerada uma patologia.

Em 2002 a Resolução $\mathrm{n}^{\circ} 1.482 / 97$ foi substituída pela Resolução $\mathrm{n}^{\circ} 1.652$ (BRASIL, 2002) que, considerando o bom resultado estético e funcional do procedimento transexualizador para adequação do fenótipo masculino para o feminino, retirou o caráter experimental da cirurgia de neocolpovulvoplastia e liberou sua realização em hospitais públicos ou privados, independentemente da atividade de pesquisa, desde que seguidos os critérios de acompanhamento estabelecidos.

39 Lei Argentina $\mathrm{n}^{\circ} .26 .734$ de 2012, disponível em <http://www.infoleg.gov.ar/infolegInternet/anexos/195000 199999/197860/norma.htm>.

${ }^{40}$ Cirurgia para construção de uma neovagina, a partir da retirada do pênis e das bolsas escrotais.

${ }^{41}$ Cirurgia de construção de um neofalo a partir de tecidos de alguma parte do corpo (antebraço, cintura, costas) que posteriormente é implantando na região genital. 
Em 2010 a Resolução foi novamente substituída pela de $\mathrm{n}^{\mathrm{o}} 1.955$ (BRASIL, 2010), atualmente em vigor. Embora essa resolução tenha mantido $\mathrm{o}$ caráter experimental das cirurgias de neofaloplastia e metoidioplastia ${ }^{42}$ para a adequação do fenótipo feminino para o masculino -, limitando sua realização a hospitais universitários ou hospitais públicos adequados para a pesquisa, passou a autorizar profissionais da rede privada de saúde a realizarem procedimentos complementares sobre as gônadas e caracteres sexuais secundários de transhomens - como, por exemplo, a retirada de útero, ovários e mamas.

Além da Resolução $\mathrm{n}^{\mathrm{o}}$ 1.955/10, do Conselho Federal de Medicina (CFM), outro documento específico sobre transexualidade atualmente vigente no Brasil é a Portaria $\mathrm{n}^{\circ} 2.803$, de 2013, do Ministério da Saúde (BRASIL, 2013b), que redefiniu e ampliou o processo transexualizador no âmbito do Sistema Único de Saúde (SUS).

Tal portaria buscou atender ao quanto determinado em sede de execução nos autos da Ação Civil Pública de $\mathrm{n}^{\circ}$ 2001.71.00.0262799/RS, que determinou ao Ministério da Saúde o cumprimento integral das medidas necessárias para possibilitar a realização, no Sistema Único de Saúde, de todos os procedimentos médicos para garantir a cirurgia de transgenitalização e a readequação sexual no Processo Transexualizador, conforme os critérios estabelecidos na respectiva Resolução do Conselho Federal de Medicina.

Tal portaria dispõe expressamente que o processo transexualizador se destina tanto a transexuais quanto a travestis e que as diretrizes de assistência devem orientar-se para a “integralidade da atenção à saúde, não restringindo ou centralizando a meta terapêutica

\footnotetext{
${ }^{42}$ Técnica cirúrgica de construção de um pequeno pênis a partir da liberação dos ligamentos internos do clitóris para que ele aumente de tamanho e que tem sido considerada
}

às cirurgias de transgenitalização e demais intervenções sobre o corpo" (BRASIL, 2013b, p.1).

Por outro lado, a Resolução $n^{\circ} 1.955 / 10$ do CFM, anteriormente citada e com a qual a Portaria do Ministério da Saúde dialoga diretamente, define o transexual como "paciente portador de desvio psicológico permanente [...], com rejeição do fenótipo e tendência à automutilação e/ou autoextermínio" (BRASIL, 2010, p.1), alçando a cirurgia de transgenitalização como "etapa mais importante no tratamento de pacientes com transexualismo [sic]" (BRASIL, 2010, p.1).

A Resolução estabelece, como critérios diagnósticos mínimos, "o desconforto com o sexo anatômico natural, o desejo expresso de eliminar os genitais e perder as características primárias e secundárias do próprio sexo e ganhar as do sexo oposto, a permanência desses distúrbios de forma contínua e consistente por, no mínimo, dois anos, e a ausência de outros transtornos mentais" (BRASIL, 2010, p. 2-3, grifos nossos).

Assim, diante de normativas tão intimamente relacionadas e, ao mesmo tempo, tão antagônicas, é possível questionar se de fato a visão da transexualidade como uma patologia cujo "portador" por excelência seria a pessoa que deseja realizar a transgenitalização, foi efetivamente rompida, tal como pretenderia a Portaria do Ministério da Saúde de 2013.

Arán et al. (2009) destacam que "a busca pela efetivação dos princípios de universalidade e integralidade da atenção à saúde, preconizados constitucionalmente desde 1988 e afirmados pela Lei $\mathrm{n}^{\circ}$ 8.080, de 1990, encontram na ideia de equidade sua condição de possibilidade" (ARÁN; MURTA; LIONÇO, 2009, p. 1146). Nesse sentido, dizem as autoras que:

[...] as políticas de promoção da equidade dependem da participação social na gestão das políticas

mais satisfatória que a técnica tradicional (neofaloplastia) pois a sensibilidade do clitóris é preservada. 
públicas [de modo que] a gestão participativa e o protagonismo do movimento social são fundamentais para que ações em saúde venham a responder e espelhar as reais necessidades e os valores específicos de diferentes grupos sociais (ARÁN; MURTA; LIONÇO, 2009, p. 1146).

As autoras destacam que em se tratando de transexualidade, "a importância do acesso aos serviços de saúde consiste não apenas no cuidado do processo de saúde-doença, mas fundamentalmente numa estratégia de construção de si” (ARÁN; MURTA; LIONÇO, 2009, p. 1142).

Quanto ao processo assistencial atualmente disponível na rede pública brasileira, ele em geral compreende:

[...] a avaliação e acompanhamento psiquiátrico periódico para confirmação do diagnóstico; psicoterapia individual e de grupo; hormonioterapia, com o objetivo de induzir o aparecimento de caracteres sexuais secundários compatíveis com a identificação psicossexual do paciente; avaliação genética; tratamento cirúrgico. Além disso, vários desses serviços já estabelecem contato com uma assessoria jurídica, para indicação de pacientes operados no processo de mudança de nome (ARÁN; MURTA; LIONÇO, 2009, p. 1142).

\subsection{A retificação de nome e da menção de sexo no registro civil de transgêneros}

No que se refere ao âmbito registral, embora no Brasil existam leis municipais, estaduais, distritais e federais esparsas garantindo o respeito ao uso do nome social ${ }^{43}$ em repartições públicas e instituições educacionais e de saúde ${ }^{44}$ independentemente da realização de qualquer

\footnotetext{
43 Aquele escolhido pela pessoa de acordo com sua identidade de gênero

${ }^{44}$ Como exemplo cite-se a Portaria ${ }^{\circ} 233$ de 2010, do Ministério do Planejamento, Orçamento e Gestão, que assegura o uso do nome social a servidores travestis e transexuais nos órgãos componentes da administração pública federal direta, autárquica e fundacional; a Resolução $\mathrm{n}^{\mathbf{0}} 14$ de 2011, do Conselho Federal de Psicologia, que autoriza a inclusão do nome social na carteira de identidade profissional; o Decreto Municipal $\mathrm{n}^{\circ}$ 51.180 de 2010, que assegura a utilização do nome social de travestis e transexuais nos órgãos municipais da
}

modificação corporal, bastando que se manifeste o desejo de ser identificado de acordo com seu gênero de identificação, por outro lado e ao contrário de outros da América do Sul, como Equador $^{45}$, Colômbia ${ }^{46}$, Argentina ${ }^{47}$ e Uruguai $^{48}$, o Brasil não possui uma lei de identidade de gênero ou legislação semelhante que regule a retificação registral de nome ou de nome e sexo no registro civil de pessoas trans que assim o desejem, embora haja projeto de lei nesse sentido, o PL n ${ }^{\circ} 5002$, objeto de análise à frente.

Assim, quando se pretende a retificação registral, que vai muito além do uso do nome social - geralmente não reconhecido justamente nos espaços e circunstâncias de maior vulnerabilidade social -, e abrange também a retificação da anotação do sexo, as pessoas têm de se socorrer ao judiciário, em geral fundamentando suas demandas nos princípios constitucionais e em dispositivos esparsos sobre direitos de personalidade da legislação civilista infraconstitucional.

Entre os princípios constitucionais acionados nesse tipo de demanda estão os da cidadania, da dignidade humana, da não discriminação, da igualdade, da intimidade e da aplicação imediata dos direitos e garantias fundamentais, expressos respectivamente nos $\operatorname{artigos} 1^{\circ}$ incisos II e III, art. $3^{\circ}$ inciso IV, art. $5^{\circ}$ caput, inciso $\mathrm{X}$ e $\S 1^{\circ}$ da Constituição Federal $(\mathrm{CF})$, in verbis:

Art. $1^{\circ}$ A República Federativa do Brasil, formada pela união indissolúvel dos Estados e Municípios e

administração direta e indireta da cidade de São Paulo e a Deliberação CEE n ${ }^{\circ} 125 / 2014$, que dispõe sobre a inclusão de nome social nos registros escolares das instituições públicas e privadas no sistema de ensino do Estado de São Paulo.

${ }^{45}$ Ley Orgánica de Gestión de la Identidad y Datos Civiles, aprovada em 10 de dezembro de 2015

${ }^{46}$ Decreto Executivo n. 1227, de 5 de junho de 2015.

${ }^{47}$ Lei $\mathrm{n}^{\circ} 26.743$, de 09/05/2012

${ }^{48}$ Lei no 18.620 , de 12/10/2009 
do Distrito Federal, constitui-se em Estado Democrático de Direito e tem como fundamentos: [...] II - a cidadania; III - a dignidade da pessoa humana (BRASIL, 1988).

[...]

Art. $3^{\circ}$ Constituem objetivos fundamentais da República Federativa do Brasil: IV - promover o bem de todos, sem preconceitos de origem, raça, sexo, cor, idade e quaisquer outras formas de discriminação (BRASIL, 1988).

[...]

Art. $5^{\circ}$ Todos são iguais perante a lei, sem distinção de qualquer natureza, garantindo-se aos brasileiros e aos estrangeiros residentes no País a inviolabilidade do direito à vida, à liberdade, à igualdade, à segurança e à propriedade, nos termos seguintes: [...] $\mathrm{X}$ - são invioláveis a intimidade, a vida privada, a honra e a imagem das pessoas, assegurado o direito a indenização pelo dano material ou moral decorrente de sua violação; [...] $\S 1^{\circ}$ As normas definidoras dos direitos e garantias fundamentais têm aplicação imediata (BRASIL, 1988).

\section{Já os artigos do Código Civil (CC) e da Lei} de Registros Públicos (LRP) concernentes ao direito ao nome e às possibilidades e modos de sua modificação geralmente citados são os artigos 11 e 16 do Código Civil e os artigos 29, $\$ 1^{\circ}$, alínea 'f'; 55, § único; 57; 58; 109 e 110 da Lei de Registros Públicos.

Os artigos 11 e 16 do $\mathrm{CC}$ encontram-se no capítulo dos direitos da personalidade e têm os seguintes dizeres, in verbis:

Art. 11. Com exceção dos casos previstos em lei, os direitos da personalidade são intransmissíveis e irrenunciáveis, não podendo o seu exercício sofrer limitação voluntária (BRASIL, 2002a).

[...]

Art. 16. Toda pessoa tem direito ao nome, nele compreendidos o prenome e o sobrenome (BRASIL, 2002a).

Já a Lei de Registros Públicos (1973) traz, entre outras, as seguintes disposições sobre o registro do nome:

Art. $29 \S 1^{\circ}$ alínea $f$ : Serão [averbados] no registro civil de pessoas naturais as alterações ou abreviaturas de nomes (BRASIL, 1973).

[...]

Art. 55, § único: Os oficiais do registro civil não registrarão prenomes suscetíveis de expor ao ridículo os seus portadores [...] (BRASIL, 1973).

\section{[...]}

Art. 57. A alteração posterior de nome, somente por exceção e motivadamente, após audiência do Ministério Público, será permitida por sentença do juiz a que estiver sujeito o registro, arquivando-se o mandado e publicando-se a alteração pela imprensa, ressalvada a hipótese do art. 110 desta Lei (BRASIL, 1973).

[...]

Art.58. O prenome será definitivo, admitindo-se, todavia, a sua substituição por apelidos públicos notórios (BRASIL, 1973).

[...]

Art. 109. Quem pretender que se restaure, supra ou retifique assentamento no Registro Civil, requererá, em petição fundamentada e instruída com documentos ou com indicação de testemunhas, que o Juiz o ordene, ouvido o órgão do Ministério Público e os interessados, no prazo de cinco dias, que correrá em cartório (BRASIL, 1973).

[...]

Art. 110. Os erros que não exijam qualquer indagação para a constatação imediata de necessidade de sua correção poderão ser corrigidos de ofício pelo oficial de registro no próprio cartório onde se encontrar o assentamento, mediante petição assinada pelo interessado, representante legal ou procurador, independentemente de pagamento de selos e taxas, após manifestação conclusiva do Ministério Público (BRASIL, 1973).

Por fim, também são aplicáveis ao caso os artigos $4^{\circ}$ da Lei de Introdução às Normas do Direito Brasileiro (LINDB) e 140 do Código de Processo Civil (CPC), in verbis:

Art. $4^{\circ}$, LINDB. Quando a lei for omissa, o juiz decidirá o caso de acordo com a analogia, os costumes e os princípios gerais de direito (BRASIL, 1942).

[...]

Art. 140, CPC. O juiz não se exime de decidir sob a alegação de lacuna ou obscuridade no ordenamento jurídico (BRASIL, 2015).

\subsection{O projeto de lei de identidade de gênero brasileiro}

Visando assegurar e regulamentar a retificação do registro civil de pessoas trans, e m vinte de fevereiro de 2013 os deputados federais Jean Wyllys (PSOL/RJ) e Érika Kokay (PT/DF) apresentaram à Câmara dos Deputados Federais o projeto de lei $\mathrm{n}^{\mathrm{o}}$ 5.002, denominado "Projeto de 
Lei sobre Identidade de Gênero - Lei João W. Nery". ${ }^{49} \mathrm{O}$ projeto, que dispõe sobre o direito à identidade de gênero e, entre outras coisas, visa alterar o artigo 58 da Lei de Registros Públicos ${ }^{50}$, é claramente inspirado na lei de identidade de gênero argentina ${ }^{51}$, já analisada.

A proposição foi distribuída para análise, nos termos regimentais, às Comissões de Direitos Humanos e Minorias, de Seguridade Social e Família, de Finanças e Tributação, de Constituição e Justiça e de Cidadania, todas da Câmara dos Deputados Federais. Até o momento o projeto foi analisado apenas pela Comissão de Direitos Humanos e Minorias, onde recebeu parecer favorável em 10 de novembro de 2015, assinado pelo deputado Luiz Albuquerque Couto (PT/PB), e segue para análise nas demais Comissões ainda sem previsão de votação pelo plenário dessa Casa, a quem caberá a apreciação final.

O texto do projeto de lei de identidade de gênero brasileiro é composto de doze artigos, os quais abordam a definição do direito tutelado, a forma como se dará seu exercício, os requisitos exigidos, a sua aplicação a pessoas menores de idade, bem como os trâmites legais, os efeitos, os limites, a aplicação, etc.

O artigo primeiro do projeto inicia reconhecendo a todas as pessoas o direito:

[...] I - ao reconhecimento de sua identidade de gênero; II - ao livre desenvolvimento de sua pessoa conforme sua identidade de gênero; III - a ser tratada de acordo com sua identidade de gênero e, em particular, a ser identificada dessa maneira nos instrumentos que acreditem sua identidade pessoal a respeito do/s prenome/s, da imagem e do sexo com que é registrada neles (BRASIL, 2013a, p.1).

$\mathrm{O}$ artigo segundo dispõe que se entende por

\footnotetext{
${ }^{49} \mathrm{O}$ nome do projeto é uma homenagem a João W. Nery, considerado o primeiro transhomem operado no Brasil, autor da autobiografia "Viagem Solitária", da Editora Leya Brasil, lançado em 2011, vide informações disponíveis em http://jeanwyllys.com.br/wp/projeto-de-jean-wyllyshomenageia-o-primeiro-transhomem-brasileiro
}

identidade de gênero a "vivência interna e individual do gênero tal como cada pessoa o sente, a qual pode corresponder ou não com o sexo atribuído após o nascimento" (BRASIL, 2013a, p.1), e que:

[...] o exercício do direito à identidade de gênero pode envolver a modificação da aparência ou da função corporal através de meios farmacológicos, cirúrgicos ou de outra índole, desde que isso seja livremente escolhido, e outras expressões de gênero, inclusive vestimenta, modo de fala e maneirismos (BRASIL, 2013a, p.1).

$\mathrm{O}$ artigo seguinte $\left(3^{\circ}\right)$ dispõe que "toda pessoa poderá solicitar a retificação registral de sexo e a mudança do prenome e da imagem registradas na documentação pessoal, sempre que não coincidam com a sua identidade de gênero auto percebida" (BRASIL, 2013a, p. 2). Entre os únicos requisitos para tal solicitação, segundo o disposto no artigo quarto, está que o demandante seja maior de dezoito anos e apresente ao cartório uma solicitação escrita requerendo a retificação registral da certidão de nascimento e informe o prenome escolhido para a emissão de uma nova carteira de identidade, a qual conservará o número original (BRASIL, 2013a).

O parágrafo único do artigo quarto continua dispondo expressamente que "em nenhum caso serão requisitos para alteração do prenome [a submissão a] intervenção cirúrgica de transexualização total ou parcial, [a] terapia hormonal [ou] qualquer outro tipo de tratamento ou diagnóstico psicológico ou médico, [nem] autorização judicial" (BRASIL, 2013a, p. 2).

Com relação às pessoas que ainda não tenham dezoito anos de idade diz o artigo quinto que:

${ }^{50}$ In verbis: "O prenome será definitivo, admitindo-se, todavia, a sua substituição por apelidos públicos notórios" (BRASIL, 1973).

51 Lei Argentina no. 26.734 de 2012, disponível em <http://www.tgeu.org/sites/default/files/ley_26743.pdf>. 
[...] a solicitação do trâmite deverá ser efetuada através de seus representantes legais e com a expressa conformidade da vontade da criança ou adolescente, levando em consideração os princípios de capacidade progressiva e interesse superior da criança, de acordo com o Estatuto da Criança e do Adolescente (BRASIL, 2013a, p. 2)

Em relação ao trâmite, dispõe o artigo sexto que:

[...] Cumpridos os requisitos [...], sem necessidade de nenhum trâmite judicial ou administrativo, o/a funcionário/a autorizado do cartório procederá: I - a registrar no registro civil das pessoas naturais a mudança de sexo e prenome/s; II - emitir uma nova certidão de nascimento e uma nova carteira de identidade que reflitam a mudança realizada; III informar imediatamente os órgãos responsáveis pelos registros públicos para que se realize a atualização de dados eleitorais, de antecedentes criminais e peças judiciais (BRASIL, 2013a, p. 2-3)

$\mathrm{O}$ artigo sexto também estabelece, em seus parágrafos, ser proibida qualquer referência, nos novos documentos, à identidade anterior, salvo com autorização por escrito da pessoa trans, bem como que os trâmites serão gratuitos, pessoais, sigilosos, não sendo necessária a intervenção de advogados ou gestores (BRASIL, 2013a).

Quanto aos efeitos da retificação, dispõe o artigo sétimo que a alteração do prenome não alterará a titularidade dos direitos e obrigações jurídicas anteriores à mudança registral, "nem daqueles que provenham das relações próprias do direito de família em todas as suas ordens e graus [...], incluída a adoção" (BRASIL, 2013a, p. 3). Dispõem os parágrafos do citado artigo que "da alteração do prenome em cartório prosseguirá, necessariamente, a mudança de prenome e gênero em qualquer outro documento" (BRASIL, 2013a, p. 3).

Dispõe também que ficará preservada a maternidade ou paternidade da pessoa trans no registro civil de seus/suas filhos/as e que isso prevalecerá inclusive "independente da vontade da outra maternidade ou paternidade" (BRASIL, 2013a, p. 3). Também, que será igualmente preservado "o matrimônio da pessoa trans [...] independente de configurar uma união homoafetiva ou heteroafetiva" (BRASIL, 2013a, p. 3-4).

Os artigos oitavo e nono seguem tratando do direito à realização de "intervenções cirúrgicas totais ou parciais de transexualização [...] e/ou tratamentos hormonais integrais, a fim de adequar seu corpo à sua identidade de gênero auto percebida" (BRASIL, 2013a, p. 4), devendo os mesmos ser oferecidos gratuitamente pelo Sistema Único de Saúde (SUS). Nesses casos, não será necessário, “em nenhum caso, qualquer tipo de diagnóstico ou tratamento psicológico ou psiquiátrico, [nem] autorização judicial ou administrativa" (BRASIL, 2013a, p. 4).

$\mathrm{O}$ artigo dez, por sua vez, dispõe sobre a proteção da identidade de gênero das "pessoas que usem um prenome distinto daquele que figura na sua carteira de identidade e ainda não tenham realizado a retificação registral" (BRASIL, 2013a, p. 4). O artigo onze dita que "nenhuma norma, regulamentação ou procedimento poderá limitar, restringir, excluir ou suprimir o exercício do direito à identidade de gênero das pessoas, devendo-se interpretar e aplicar as normas sempre em favor do acesso a esse direito" (BRASIL, 2013a, p. 4).

Por fim, o artigo 12 do projeto propõe a modificação do artigo 58 da Lei de Registros Públicos (Lei 6.015/73) para que sua redação passe a ser: "O prenome será definitivo, exceto nos casos de discordância com a identidade de gênero auto percebida, para os quais se aplicará a lei de identidade de gênero. Admite-se também a substituição do prenome por apelidos públicos notórios" (BRASIL, 2013a, p. 4).

\section{CONCLUSÃO}

O presente artigo buscou apresentar uma visão geral e comparativa sobre o estado da questão da retificação registral para pessoas 
transgênero nos dez países da América do Sul que são também integrantes do sistema interamericano de direitos humanos da OEA. Como estabelecido pela Comissão Internacional de Juristas (CIJ, 2011) ${ }^{52}$ e concluído por diversos estudos feitos junto à comunidade transgênero, a retificação é de extrema importância para a garantia da cidadania e da dignidade das pessoas trans, por vezes até mais importante que a obtenção de procedimentos cirúrgicos de redesignação sexual, na medida em que a identificação civil é imprescindível para a maior parte das atividades quotidianas das pessoas.

Entretanto, viu-se que ainda hoje, na maioria dos países analisados, o direito à retificação registral no caso das pessoas trans é majoritariamente condicionado à prévia realização de intervenções corporais de redesignação sexual ou, no mínimo, ao diagnóstico médico de disforia de gênero. Dos dez países analisados, apenas Equador, Colômbia e Argentina, e apenas muito recentemente, não patologizam as experiências trans, enquanto Uruguai, embora tenha sido o primeiro país a aprovar uma lei de identidade de gênero de âmbito nacional, ainda tutela as pessoas trans a partir do marco patologizante.

Assim, a maioria dos países, tal como o Brasil, além de não possuírem lei de identidade de gênero, em geral condicionam a retificação da menção de sexo dessas pessoas, cuja decisão cabe ao judiciário, à prova do diagnóstico de disforia de gênero e até mesmo à realização de procedimentos de redesignação sexual, independentemente do desejo ou possibilidade das pessoas. Por fim, Venezuela e Paraguai sequer autorizam a retificação registral para aquelas

\footnotetext{
52 Conjunto de especialistas em Direitos Humanos que ajudaram a redigir os Princípios de Yogyakarta.

${ }^{53}$ No âmbito do Sistema da Convenção Americana de Direitos Humanos da Organização dos Estados Americanos (CADH-OEA) a Resolução n $^{\circ}$ 2435, adotada em 3 de junho de 2008 pela Assembleia Geral da OEA, órgão máximo da Organização, foi a primeira dedicada especificamente aos
}

pessoas que já hajam se submetido ao processo transexualizador completo.

Essa situação, que se origina de uma concepção biologizante sobre a relação entre anatomia dos corpos e expressão de gênero, revela um padrão discriminatório no acesso a direitos da população trans que acaba resultando na patologização da vivência subjetiva de gênero dessas pessoas, em dissonância tanto com os princípios gerais do Direito Internacional dos Direitos Humanos, como os princípios da igualdade e da liberdade, quanto com aqueles constantes dos documentos específicos sobre identidade de gênero, como os princípios da privacidade, da não discriminação e do reconhecimento jurídico da personalidade.

No Brasil, a despeito da existência de projeto de lei pendente na Câmara dos Deputados, o legislativo brasileiro permanece omisso em seu dever de aprovar uma legislação específica que avance no reconhecimento de direitos à população trans. Pode-se dizer que tal omissão legislativa representa uma violação dos compromissos internacionais assumidos pelo Brasil tanto convencionalmente e em caráter obrigatório, no âmbito da Convenção Americana de Direitos Humanos (OEA, 1969) 53 , quanto diplomaticamente, quando patrocinou, junto com Argentina e Uruguai, os Princípios de Yogyakarta (ONU, 2007).

A falta de legislação, entretanto, tampouco justifica a permanência de uma interpretação, pelo judiciário, discrepante com os parâmetros internacionais de direitos humanos aos quais o Brasil voluntariamente manifestou adesão. Isso porque também o judiciário é espaço juridicamente qualificado para problematizar a

direitos humanos em sua vinculação com a orientação sexual e identidade de gênero. Tal resolução pioneira se antecipou inclusive à iniciativa similar da ONU, que em dezembro do mesmo ano (2008) emitiu sua primeira declaração sobre orientação sexual e identidade de género no âmbito de sua Assembleia Geral. 
constituição pelos saberes médico e psiquiátrico de determinadas existências humanas consideradas, unicamente com base em sua expressão de gênero contra majoritária, como menos capazes de decidir sobre aspectos personalíssimos de sua vida que outras.

O fato é que a despeito da tradição liberal postular que os direitos humanos se vinculam aos sujeitos na qualidade de indivíduos e não de membros de uma comunidade política concebida como fonte dos direitos políticos, e embora os fundamentos axiológicos dos Direitos Humanos encontrem-se assentados sobre uma noção metafísica ou ontológica de humanidade, é falacioso achar que se possa definir o sujeito do direito a partir de uma perspectiva meramente jurídico-formal, na medida em que permanece a questão moral sobre quais são as características que tornariam uma pessoa digna de estima e respeito em determinado contexto históricocultural (RICOEUR, 2008).

No caso das pessoas transgênero, aparentemente o simples reconhecimento de sua humanidade não tem sido suficiente para garantirlhes os direitos humanos mais básicos $\mathrm{e}$ fundamentais, como a ser corretamente identificado civilmente. Trata-se, portanto, de questionar uma "matriz de reconhecimento [que] exclui de seus marcos aquelas/es que deslocam as definições de feminino e masculino" (BENTO, 2011, p. 99), um conceito de humano, portanto, "que retira humanidade daqueles que não tem um gênero compatível com o sexo" (BENTO, 2011, p. 91).
Assim é que, embora - e justamente porque - seja por meio do Direito que se aceda à vida para além da mera existência biológica, é ele também quem tem o poder de decidir sobre seu início, seu modo adequado e seu fim. Portanto, faz-se necessária uma reflexão sobre a função que os legisladores e operadores do Direito têm exercido - ou deixado de exercer - delegando a tarefa de regulação dos conflitos sociais que lhes cabe a saberes externos ao campo jurídico, como os saberes médicos e $p s i$, que ao serem reproduzidos sem problematização e aplicados irrefletidamente sem ponderação com valores éticos e princípios jurídicos, tendem a resultar na instrumentalização do Direito a serviço de uma questionável objetividade científica.

Como a história mundial recente testemunha, quando a vida humana é subordinada ao discurso biomédico ela finda por se tornar uma vida meramente biológica - a vida nua de que Agamben (2002) nos fala. E, destituída da complexidade que a distingue como humana, fica vulnerável aos riscos historicamente conhecidos de sua instrumentalização por tais saberes. Indivíduos reduzidos à mera existência biológica, como muitas vezes as pessoas trans os são, têm sua existência política e cidadã tornada precária, já que seu reconhecimento jurídico não decorre exclusivamente de sua humanidade strictu sensu, mas passa pela análise quanto ao cabimento de sua existência dentro de algum dos modos normativos - e só então tuteláveis - de se ser humano.

\section{REFERÊNCIAS}

AGAMBEN, Giorgio. Homo Sacer: O Poder Soberano e a Vida Nua I, trad. Henrique Burigo, $2^{\mathrm{a}}$ ed., Belo Horizonte: Editora UFMG, 2002.

APA, American Psychiatric Association. Diagnostic and Statistical Manual of Mental Disorders: DSM-V. 5th ed. Arlington, Virginia: APA Publishing, 2013. 
ARÁN, Márcia. A transexualidade e a gramática normativa do sistema sexo-gênero. Ágora: Estudos em Teoria Psicanalítica, Rio de Janeiro, v. 9, n. 1, p. 49-63, 2006.

; MURTA, Daniela; LIONÇO, Tatiana. Transexualidade e saúde pública no Brasil. Ciênc. saúde coletiva. Rio de Janeiro, v. 14, n. 4, p. 1141-1149, 2009. Disponível em: $<$ http://www.scielo.br/scielo.php?script=sci_arttext\&pid=S141381232009000400020\&lng=en \&nrm=iso.

ARGENTINA. Ley $n^{o}$ 26.743. Buenos Aires, 2012. Disponível em: <http://www.infoleg.gov.ar/infolegInternet/anexos/195000-199999/197860/norma.htm>.

BOLÍVIA. Nova Constituição Política do Estado. La Paz, 2009. Disponível em: <http://www.oas.org/juridico/spanish/mesicic3_blv_constpolitica.pdf>.

Código Penal Boliviano. La Paz, 1972. Disponível em:

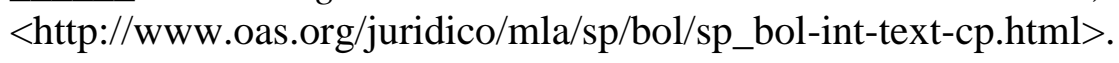

BRASIL. Constituição da República Federativa do Brasil de 1988. Brasília: Diário Oficial da União, 5 de outubro de $1988 . \quad$ Disponível em: <http://www.planalto.gov.br/ccivil_03/constituicao/ConstituicaoCompilado.htm>.

Lei $n^{\circ} 4.657$, de 4 de setembro de 1942. Institui a Lei de Introdução às normas do Direito Brasileiro. Brasília: Diário Oficial da União, 9 de setembro de 1942. Disponível em: <http://www.planalto.gov.br/ccivil_03/decreto-lei/Del4657compilado.htm.

. Lei $n^{\circ} 6.015$, de 31 de dezembro de 1973. Dispõe sobre os registros públicos e dá outras providências. Brasília: Diário Oficial da União, 31 de dezembro 1973. Disponível em: <http://www.planalto.gov.br/ccivil_03/leis/L6015original.htm>.

. Lei $n^{\circ} 8.080$, de 19 de setembro de 1990. Dispõe sobre as condições para a promoção, proteção e recuperação da saúde, a organização e o funcionamento dos serviços correspondentes e dá outras providências. Brasília: Diário Oficial da União, 20 de setembro de 1990. Disponível em: <http://www.planalto.gov.br/ccivil_03/Leis/L8080.htm>.

Lei $n^{\circ}$ 10.406, de 10 de janeiro de 2002. Institui o Código Civil. Brasília: Diário Oficial da União, 11 de janeiro 2002a. Disponível em: <http://www.planalto.gov.br/ccivil_03/leis/2002/L10406.htm>.

. Lei $n^{o}$ 13.105, de 16 de março de 2015. Institui o Código de Processo Civil. Brasília: Diário Oficial da União, 17 de março 2015. Disponível em: <http://www.planalto.gov.br/ccivil_03/leis/2002/L10406.htm>.

. Câmara dos Deputados Federais. Projeto de Lei de Identidade de Gênero (PL nº 5002/13). Brasília, 2013a. Disponível em: <www.camara.gov.br/proposicoesWeb/fichadetramitacao?idProposicao=565315>.

. Portaria do Ministério da Saúde de $n^{\circ} 2.803$, de 19 de novembro de 2013. Redefine e amplia o Processo Transexualizador no Sistema Único de Saúde (SUS). Brasília: Diário Oficial da União, 20 de novembro de 2013b. Disponível em: <http://bvsms.saude.gov.br/bvs/saudelegis/gm/2013/prt2803_19_11_2013.html>. 
. Resolução do Conselho Federal de Medicina de $n^{\circ} 1.482$ de 19 de setembro de 1997. Autoriza, a título experimental, a realização de cirurgia de transgenitalização do tipo neocolpovulvoplastia, neofaloplastia e procedimentos complementares sobre gônadas e caracteres sexuais secundários como tratamento dos casos de transexualismo. Brasília: Diário Oficial da União, 19 de setembro de 1997.

. Resolução do Conselho Federal de Medicina de $n^{o} 1.652$, de 6 de novembro de 2002. Dispõe sobre a cirurgia de transgenitalismo e revoga a Resolução CFM n 1.482/97 (revogada). Brasília: Diário Oficial da União, 2 de dezembro de 2002b.

Resolução do Conselho Federal de Medicina de $n^{o} 1.955$, de 12 de agosto de 2010. Dispõe sobre a cirurgia de transgenitalismo e revoga a Resolução CFM n ${ }^{\circ}$ 1.652/02. Brasília: Diário Oficial da União, 3 de setembro de 2010, p. 109-110. Disponível em: $h$ http://www.portalmedico.org.br/resolucoes/CFM/2010/1955_2010.htm.

. Supremo Tribunal Federal. Ação Direta de Inconstitucionalidade (ADI) nº 4275. Brasília, 21 de julho de 2009.2 Disponível <http://www.stf.jus.br/portal/geral/verPdfPaginado.asp?id=400211\&tipo=TP\&descricao=ADI $\% 2 \mathrm{~F} 4275>$.

BENTO, Berenice. Política da diferença: feminismos e transexualidade. In: COLING, Leandro (org.). Stonewall. + 40 o que no Brasil? Salvador: Edufba, 2011.

; PELÚCIO, Larissa. Despatologização do gênero: a politização das identidades abjetas. Estudos Feministas, Florianópolis, v. 20, n. 2, p. 569, ago. 2012. Disponível em: <https://periodicos.ufsc.br/index.php/ref/article/view/s0104-026x2012000200017>.

BUTLER, Judith. Corpos que pesam: sobre os limites discursivos do 'sexo'. In: LOURO, Guacira Lopes (org.). O Corpo Educado: pedagogias da sexualidade. Belo Horizonte: Autêntica, 1999.

CANGUILHEM, G. O normal e o patológico. 6.ed. Rio de Janeiro: Forense Universitária, 2009.

CASTEL, Pierre-Henri. Algumas reflexões para estabelecer a cronologia do "fenômeno transexual" (1910-1995). Rev. bras. Hist., São Paulo, v. 21, n. 41, p. 77-111, 2001. Disponível em: $<$ http://www.scielo.br/scielo.php?script=sci_arttextpid=S010201882001000200005\&lng=en \&nrm=is so>.

CHILE. Ley $n^{o}$ 20.609. Establece medidas contra la discriminación. Santiago, 2012. Disponível em: $<$ http://portales.mineduc.cl/usuarios/convivencia_escolar/doc/201311281730000.LEY20609_no_disc riminacion.pdf $>$

Proyecto de ley $n^{o}$ 8924-07. Proyecto de ley sobre Identidad de género que reconoce y da protección al derecho a la identidad de género. Santiago, 2013. Disponível em: <https://www.camara.cl/pley/pley_detalle.aspx?prmID=9331\&prmBL=8924-07>.

COLÔMBIA. Decreto Executivo $n^{o}$ 1227. Bogotá, 2015a. Disponível em: <http://wp.presidencia.gov.co/sitios/normativa/decretos/2015/Decretos2015/DECRETO\%2012 27\%20DEL\%2004\%20DE\%20JUNIO\%20DE\%202015.pdf>. 


$$
\text { Ley } \quad n^{o} \quad \text { 1.482. Bogotá, 2011. Disponível em: }
$$

<http://wsp.presidencia.gov.co/Normativa/Leyes/Documents/ley148230112011.pdf〉.

Sentencia T-063. Accion de tutela contra la registraduria nacional del estado civil. Procedencia para modificar el sexo en el registro civil de una persona transgénero vía notarial. Corte Constitucional de Colômbia, 2015b. Disponível em: <http://www.corteconstitucional.gov.co/relatoria/2015/t-063-15.htm>.

COMISSÃO INTERNACIONAL DE JURISTAS (CIJ). Sexual Orientation, Gender Identity and Justice: A Comparative Law Casebook. Genebra: International Commission of Jurists, 2011. <Disponível em: http://icj.wpengine.netdna-cdn.com/wpcontent/uploads/2012/05/Sexual-orientationgender-identity-and-Justice-report-2011.pdf $>$.

EQUADOR. Constitución del Ecuador. Lima, 2008. Disponível em: <http://www.asambleanacional.gov.ec/documentos/constitucion_de_bolsillo.pdf >.

Ley Orgánica de Gestión de la Identidad y Datos Civiles. Lima, 2015. Disponível em: <http://www.asambleanacional.gob.ec/es/noticia/40698-asamblea-aprobo-ley-de-gestion-deidentidad-se-crea>.

FREIRE, Lucas. A máquina da cidadania: uma etnografia sobre a requalificação civil de pessoas transexuais. 2015, 192 f. Dissertação (Mestrado em Antropologia Social). Museu Nacional, UFRJ, Rio de Janeiro. Disponível em: <https://www.academia.edu/11873996/A_M\%C3\%A1quina_da_Cidadania_uma_etnografia_so bre_a_requalifica\%C3\%A7\%C3\%A3o_civil_de_pessoas_transexuais>.

LAQUEUR, Thomas W. Inventando o sexo: corpo e gênero dos gregos a Freud. Rio de Janeiro: Relume Dumará, 2001.

MURTA, Daniela. A psiquiatrização da transexualidade: análise dos efeitos do diagnóstico de Transtorno de Identidade de Gênero sobre as práticas de saúde. 2007. Dissertação (Mestrado em Saúde Coletiva. Área de Concentração: Ciências Humanas e Saúde) - Instituto de Medicina Social, Universidade do Estado do Rio de Janeiro, Rio de Janeiro, 2007.

ORGANIZAÇÃO DOS ESTADOS AMERICANOS (OEA). Convenção Americana de Direitos Humanos. Pacto de San José da Costa Rica. Costa Rica, 1969.

. Resolución $n^{\circ}$ 2435/08 de la Asamblea General - Derechos Humanos, Orientación Sexual e Identidad de Género (AG/RES. 2435/XXXVIII-O/08), 2008. Disponível em: <https://www.oas.org/dil/esp/AG-RES_2435_XXXVIII-O-08.pdf>.

ORGANIZAÇÃO DAS NAÇÕES UNIDAS (ONU). Declaração A/63/635 sobre orientação sexual e identidade de género, $2008 . \quad$ Disponível em: $<$ http://old.ilga.org/news_results.asp?LanguageID=5\&FileID=1215\&ZoneID=28\&FileCategor $\mathrm{y}=32>$.

. Les principes de Jogjakarta - Principes sur l'application de la législation internationale des droits humains en matière d'orientation sexuelle et d'identité de genre. Yogyakarta, 2007. <Disponível em: http://www.yogyakartaprinciples.org/principles_fr.pdf $>$. 
ORGANIZAÇÃO MUNDIAL DA SAÚDE (OMS). Classificação Estatística Internacional de Doenças e Problemas Relacionados à Saúde (CID-10). 10a ed. São Paulo: Edusp, 2008.

PARAGUAI. Código Penal Paraguaio. Asunción, 1997. Disponível em: <http://www.oas.org/dil/esp/Codigo_Penal_Paraguay.pdf >.

- Constituição da República do Paraguai. Asunción, 1992. Disponível em: <https://www.oas.org/juridico/mla/sp/pry/sp_pry-int-text-const.pdf>.

PERU. Proyecto de ley de identidad de género. Lima, 2012. Disponível em: <https://pt.scribd.com/document/333423946/PL-de-Identidad-de-Genero-pdf>.

RICOEUR, Paul. O Justo I. São Paulo: Martins Fontes, 2008.

URUGUAI. Ley n 17.817 - Lucha contra el racismo, la xenofobia y la discriminación. Montevidéu, 2004.

Disponível

em:

<http://www0.parlamento.gub.uy/leyes/AccesoTextoLey.asp?Ley=17817\&Anchor=>.

. Ley $n^{o} 18.620$ - Derecho a la identidad de género y al cambio de nombre y sexo en documentos identificatorios. $\quad$ Montevidéu, 2009. 2 Disponível <http://www.parlamento.gub.uy/leyes/AccesoTextoLey.asp?Ley=18620\&Anchor=>.

VENEZUELA. Código Penal Venezuelano. Caracas, 2000. Disponível em: <http://www.oas.org/juridico/spanish/mesicic3_ven_anexo6.pdf>.

Constituição da República Bolivariana da Venezuela. Caracas, 1999. Disponível em: <https://www.oas.org/juridico/mla/sp/ven/sp_ven-int-const.html>.

VILARDO, Maria Aglaé Tedesco. Decisões judiciais no campo da biotecnociência: a bioética como fonte de legitimação. 2014. Tese de Doutorado em Saúde Coletiva. Área de Concentração: Bioética e Ética Aplicada - Instituto de Medicina Social, Universidade do Estado do Rio de Janeiro, Rio de Janeiro, 2014.

Recebido em: $15 / 05 / 2017$

Aceito em: 25/08/2018 
